\title{
Impact of socio-political dynamics on water and sanitation service delivery in Malawi
}

\author{
B. Thole, E. Chikhwenda \& A. Thengolose \\ Polytechnic, University of Malawi, Malawi
}

\begin{abstract}
Malawi has an area of $118,500 \mathrm{~km}^{2}$. Lake Malawi covers a third of the area. The population was $13,166,000$ for 2008 with a renewable water resource per capita of $1374 \mathrm{~m}^{3}(2003-2007)$. There is a certain degree of water stress despite a large water body and a good renewable water resource. Research was undertaken to determine impact on water and sanitation service delivery resulting from governance, planning, structure of service, the role of civil societies, NGOs and CBOs, and, the impact of water and sanitation service delivery on the livelihood of Malawians.

The results showed that the country has a water policy, but has fragmented water supply regulations. There has been a draft sanitation policy for over two years that has been recently launched but the country is still without regulations on sanitation. The five water boards often have negative net-incomes attributable to unwillingness to pay by the general public and lack of political will to allow the water boards to revise tariffs to reflect the cost of water supply. Budgetary allocations for the sector remain below $1 \%$ of total national budget; the sector depends on funding from development partners. $66.4 \%$ of households in Malawi have access to improved water source and $61.9 \%$ have improved sanitation.

Malawi needs to harmonise her water and sanitation regulatory framework and consider reviewing the tariff structure of the five water boards if the MDG target on water supply and sanitation is to be achieved by 2015 .
\end{abstract}

Keywords: water, supply, sanitation, services, policy, regulation, framework, Malawi, tariff, structure.

\section{Introduction}

Malawi has recently started experiencing a certain degree of water stress due to its high population estimated at 13,166,000 against a land area of $118,000 \mathrm{~km}^{2}$. 
The renewable water resources per capita are about $1374 \mathrm{~m}^{3}$ for the period 2003 to 2007. The sector requires careful management; however, a comprehensive management programme does not yet exist. There are efforts to expand irrigated agriculture in order to reduce the effects of weather shocks on agricultural output. While this is a positive development, it is not yet established how this will impact on water supply and sanitation for household purposes (AfDB/OECD [1]).

There are five parastatal water boards in Malawi that are Blantyre Water Board (BWB), Lilongwe Water Board (LWB), Northern Region Water Board (NRWB), Southern Region Water Board (SRWB) and Central Region Water Board (CRWB). All the five boards are often in debt and in the years 1999 to 2004 have been characterized by weak governance and political interference. One of the key Millennium Development Goals is access to safe drinking water. Integrated House hold survey shows that $66.4 \%$ of households in Malawi have access to an improved water source, where an improved water source is defined as being water piped into the dwelling, piped outside, from a communal stand pipe, or from a hand pump, borehole or protected well (NSO [2]). While this is slightly above the average for sub-Saharan Africa of $58 \%$, more concerted effort is needed if Malawi is to achieve the $75 \%$ target for all households to have safe potable water and adequate sanitation by 2015 .

\subsection{Aim}

This research aimed at determining the performance and impact of the water supply and sanitation services in Malawi through the changing socio-political landscape.

\subsection{Objectives}

Specific objectives were;

1.2.1 To analyse the national regulatory framework and its impact on water supply and sanitation in Malawi,

1.2.2 To determine constraints in water and sanitation service delivery in Malawi,

1.2.3 To identify variances in water and sanitation service delivery between rural and urban areas of the country,

1.2.4 To analyse the relationship between policy and public expenditure on water and sanitation; and

1.2.5 To determine participation of civil society and Non Governmental Organisations (NGOs) in the water and sanitation sector in Malawi.

\section{Methodology}

The methods employed involved characterisation of governance policies and frameworks, identification of determinants of policy and planning, review of the structure and performance of the service, determination of the role of civil societies, NGOs and CBOs, and, the impact of water and sanitation service 
delivery on the livelihood of Malawians. This included literature review, focus group interviews, questionnaire interviews and targeted sampling interviews. The research was based on documentary data from policy documents, annual reports, published journals, parliamentary budget speeches by the President and the minister of finance on prioritization of the national budget in the different sectors. Data was also collected from National Statistical Office, Centre for Social Research and Centre for Education Research (University of Malawi) as well as country reports. Important data was collected from key informants from civil society and NGOs such as Malawi Economic Justice Network (MEJN), Malawi Health Equity Network (MHEN), Consumer Association of Malawi and Civil Society Coalition for Quality Education (CSCQE). Use of internet was also employed for official data about service delivery in Malawi.

\section{Results and discussion}

\subsection{Water supply, sanitation and the MDGs, PRSP in Malawi}

Access to safe drinking water is one of the major aims of the United Nation's Millennium Development Goals (MDGs) to be achieved by 2015. This goal was set to reduce to half the number of people without sustainable access to safe drinking water and basic sanitation by 2015 (UN [3]). The achievement of this goal is directly linked to the achievement of other MDGs related to poverty, food, health and housing. This underlines the fact that access to clean water is central to healthy and productive livelihood for the poor yet at the onset of the 21 st century over one billion people still lacked access to safe drinking water worldwide. It has been observed that in poverty impact assessments water related indicators are poorly defined with water and sanitation weakly represented or absent in Malawi Poverty Reduction Strategy Paper (GoM [4]).

The Malawi Poverty Reduction Strategy Paper (MPRSP) is grouped according to four main pillars of poverty reduction which include rapid sustainable pro-poor economic growth and structural transformation, human capital development, improvement of the quality of life of the most vulnerable and good governance. Water and sanitation feature within the rapid sustainable pro-poor economic growth and the human capital development. The PRSP recognises that it is necessary to increase access to good drinking water and sanitation in order to achieve rapid sustainable pro-poor economic development. It also recognises that human capacity development can be achieved by improving the quality, access and equity of essential healthcare, which includes sanitation and safe water. In Malawi, rural infrastructure is deficient and there is a need to provide potable water supplies and reasonable sanitation facilities. Literature shows that equitable access to water supplies and sanitation are central to poverty reduction due to their direct links to health and productivity. The main stakeholders in the Malawi water sector are the Ministry of Irrigation and Water Development, the five water boards (BWB, LWB, SRWB, NRWB and CRWB), the private sector, NGOs and civil society organisations. International development partners also set up and fund their own water and sanitation projects (GoM [5]). 


\subsection{Water and sanitation provision in Malawi}

Piped water supplies are most common in urban areas but less prevalent in rural areas where boreholes and protected wells are the main source of potable water. The effort towards meeting the MDGs for water and sanitation will not only require substantial financial resources, but also adequate institutional arrangements, planning, and effective collaboration among a wide range of players. This, therefore, will require clear and effective leadership and action plans.

In Malawi, efforts are being made to put in place the MDGs roadmap, with varying degrees of success. These are summarized in the following table.

Table 1: $\quad$ Key milestones towards meeting MDGs.

\begin{tabular}{|c|c|c|c|c|}
\hline \multirow[t]{2}{*}{ Milestone } & \multicolumn{2}{|c|}{ Rural } & \multicolumn{2}{|c|}{ Urban } \\
\hline & WS & $\mathrm{S}$ & WS & $\mathrm{S}$ \\
\hline Institutional Leader Identified & $\mathrm{C}$ & $\mathrm{C}$ & $\mathrm{C}$ & $\mathrm{C}$ \\
\hline Stakeholder consultation & I & I & I & I \\
\hline MDG Action Plan & I & $\mathrm{N}$ & $\mathrm{C}$ & $\mathrm{N}$ \\
\hline Resources mobilized & I & I & I & $\mathrm{N}$ \\
\hline Implementation underway towards MDGs & I & $\mathrm{N}$ & I & $\mathrm{N}$ \\
\hline
\end{tabular}

WS - Water Supply, S - Sanitation, N - Not Started, I - In Progress. C - Completed.

From Table 1, it is clear that there is still need for considerable effort and inputs to complete the Roadmap. This is particularly the case with Sanitation where many activities have not yet started.

In order to improve on stakeholder consultations, broad based ownership and commitment to meeting the agreed sector programs, an annual Joint Sector Review (JSR) was scheduled for introduction in March 2008 (ADB [6]. Table 2 depicts the situation in 2005/06.

Table 2: $\quad$ Proportion of households with access to safe water and distribution of households by main source of drinking water, 2005/6.

\begin{tabular}{|l|l|l|l|l|l|l|}
\hline $\begin{array}{l}\text { Household } \\
\text { proportion with } \\
\text { access to improved } \\
\text { water source }\end{array}$ & $\begin{array}{l}\text { Piped into } \\
\text { dwelling }\end{array}$ & $\begin{array}{l}\text { communal } \\
\text { standpipe }\end{array}$ & $\begin{array}{l}\text { Hand pump } \\
\text { /borehole/ } \\
\text { protected well }\end{array}$ & $\begin{array}{l}\text { Un- } \\
\text { protected } \\
\text { well }\end{array}$ & $\begin{array}{l}\text { River, } \\
\text { springlake } \\
\text { and other }\end{array}$ \\
\hline Malawi & 66.4 & 2.2 & 17.7 & 46.5 & 25.4 & 8.2 \\
\hline Urban & 85.1 & 12.6 & 62.3 & 10.2 & 11.1 & 3.8 \\
\hline Rural & 63.9 & 0.8 & 11.7 & 51.4 & 27.3 & 8.8 \\
\hline North & 63.7 & 0.5 & 13.1 & 50.1 & 24.2 & 12.1 \\
\hline Centre & 54.3 & 0.5 & 9.2 & 44.6 & 38.6 & 7.1 \\
\hline South & 74.9 & 3.7 & 24.2 & 47.0 & 16.9 & 8.2 \\
\hline
\end{tabular}

This data is also supported by the 2006 Multiple Indicator Cluster Survey that revealed that by $2006,67 \%$ of the population in Malawi had access to improved drinking water sources. The improved sources include piped water, public tap, borehole/tubewell, protected well and protected spring. The majority were using boreholes/tubewells at $51.4 \%$, followed by piped water at $16.6 \%$, and then 
protected well at $6.0 \%$. About $0.2 \%$ was accessing safe water from other sources. Of the remaining 33\% that are still using unimproved (unsafe) sources, the majority at $19.3 \%$ are using unprotected wells, followed by surface water at $5.4 \%$.

The survey further provided a breakdown of data in rural and urban, as well as in the regions. The data showed that access to improved water supply in the urban areas is at $85.1 \%$ while in the rural it is at $63.9 \%$. At regional level, the Southern Region has the highest coverage at $74.9 \%$, followed by the Northern Region at $63.7 \%$, while the Central Region has the lowest coverage at $54.3 \%$.

The Intergrated Household Survey of 2005 indicates that $61.9 \%$ of households in Malawi have access to improved sanitation facilities. Improved sanitation is defined as flush toilet, a ventilation-improved (VIP) latrine or a traditional latrine with a roof. This is quite higher than the sub-Saharan Africa average of $36 \%$. It is important to note that access to improved sanitation, as with access to safe potable water, is higher in the urban areas as compared to rural areas (Table 3) (GoM [7]).

Table 3: Proportion of households with proper toilet sanitation and distribution of households by type of toilet facility, 2005.

\begin{tabular}{|l|l|l|l|l|l|l|l|}
\hline & $\begin{array}{l}\text { Household } \\
\text { proportion } \\
\text { with access } \\
\text { to improved } \\
\text { sanitation }\end{array}$ & $\begin{array}{l}\text { Flush } \\
\text { toilet }\end{array}$ & $\begin{array}{l}\text { VIP } \\
\text { latrine }\end{array}$ & $\begin{array}{l}\text { Traditional } \\
\text { latrine with } \\
\text { roof }\end{array}$ & $\begin{array}{l}\text { Traditional } \\
\text { latrine } \\
\text { without } \\
\text { roof }\end{array}$ & None & Other \\
\hline Malawi & 61.9 & 2.8 & 1.8 & 57.4 & 20.9 & 16.9 & 0.3 \\
\hline Urban & 78.3 & 14.0 & 3.9 & 60.4 & 18.8 & 2.9 & 0.0 \\
\hline Rural & 59.7 & 1.2 & 1.5 & 56.9 & 21.2 & 18.8 & 0.3 \\
\hline North & 53.7 & 0.8 & 0.9 & 52.0 & 35.0 & 11.1 & 0.2 \\
\hline Centre & 63.9 & 1.4 & 1.0 & 61.5 & 15.1 & 20.7 & 0.3 \\
\hline South & 62.0 & 4.0 & 2.5 & 55.5 & 22.3 & 15.4 & 0.3 \\
\hline
\end{tabular}

The 2006 Multiple Indicator Cluster Survey showed an improvement in the sanitation sector with about $28 \%$ without safe human waste disposal system.

\subsection{Determinants of policy and planning}

The drivers to improving service delivery in the water and sanitation sector include the existence of a legal framework for water supply, positive political atmosphere for donor support, community participation and a well structured water supply system within the cities and geographic regions. The overall legal institution in water and sanitation in Malawi is the Ministry of Irrigation and Water Development (MoIWD). Through this ministry the Water Resources Act was enacted in 1969 and a draft bill for its revision has been prepared for 2008. Malawi also has a National Water Policy that was first drafted and launched in 1994. The policy was revised in 2005 (MoIWD [8]). This policy has been launched in 2008, 14 years after its inception. This is indicative of historic negligence of sanitation issues at national level. The Water Works Act of 1995 [9] established five water boards. All the five water boards in Malawi, BWB, 
SRWB, CRWB, LWB and NRWB, have been able to acquire long term loans from the donor community such as UNICEF, ADB, OPEC Fund, World Bank, DFID, and others. This is attributed to a positive political atmosphere from 2004 to presently, i.e. good governance, accountability and policy support in water supply (AFRODAD [10]). The Water Works Act is being revised to recognize community participation and allow private investor participation in water supply. Community participation in water resource management, though not clearly stipulated in the Water Works Act, has been encouraged since 1994 in high density areas of the city and in rural areas.

Constraints to improving service delivery include low budgetary allocation to water services, categorization of water boards as commercial entities vis-à-vis the water tariff structure, unwillingness to pay for water by some consumers, the social dimension and citizens' perception of water, the disjointed sanitation legislation, and others. Recently there have been low budgetary allocations towards water services as exemplified by the percentage proportion of the national budget in 2007. A simple comparison of percentage budgetary allocation for four sectors is depicted in table 4 .

Table 4: $\quad$ Percentage budgetary allocation for four sectors in Malawi, 2007.

\begin{tabular}{|l|l|}
\hline Sector & Percentage Budgetary Allocation \\
\hline Agriculture & 14 \\
\hline Health & 11 \\
\hline Education & 11 \\
\hline Water & 0.8 \\
\hline
\end{tabular}

This data shows that government allocated less than $1 \%$ of the national total budget to water services in 2007 against 14\%, 11\% and 11\% to agriculture, health and education respectively. The data clearly illustrates that water services are lowly ranked in terms of financing which is contradictory to the high ranking of this sector in the country's PRSP. The sector however thrives on finances from the donor community. These include WaterAid, UNICEF, World Bank, ADB, DFID and others. A typical example is the National Water Development Programme (NWDP) designed by the Ministry of Irrigation and Water Development worth U\$ $144 \mathrm{~m}$ and of five years duration. The World Bank as lead donors alongside UNICEF, EIB, EC and CIDA has committed US\$90m leaving a shortfall of US $\$ 50 \mathrm{~m}$. The programme aims at achieving $80 \%$ of water coverage by 2011. The World Bank' Malawi Office is further bidding to the Bank's Africa Catalytic Growth Fund for US\$25m for the programme. DFID is another agency using its influence and support to ensure that investments from others are targeted equitably and in a sustainable manner by engaging in the sector planning behind NWDP II, investing in school water and sanitation as part of the funding to the education sector (approx. $£ 2.5 \mathrm{~m}$ in water and sanitation alone in the past 3 years), and co-financing Concern Universal on EU Water Facility project providing access for 202, 500 people (DFID [11]).

All the five water boards in Malawi are placed in the commercial category (GoM [12, 13]). This implies that the water boards do not get any government 
subvention, the implication of which being that the water boards must generate sufficient finances for all their operations, maintenance and development. Further more, the boards are expected to submit dividends to government. This situation requires appropriate pricing of water with respect to production, operation, and development cost. Unfortunately the water tariffs are mostly lower than the production costs. The production of safe potable water averages 0.25 Malawi Kwacha per litre and yet the selling price mean is at 0.20 Malawi Kwacha per litre. Proposals to increase water tariffs by water boards often receive negative publicity and are usually rejected by government. This is attributed to the perception that water is a social good and all citizens have a right to water. Any government of the day is unwilling to allow appropriate water tariff adjustments against this background for fear of losing political mileage.

Unwillingness to pay by some consumers is also a challenge water boards are facing. It is worth noting that the largest debtors of water boards are government institutions that are not easy to disconnect because of the nature of their services and sociopolitical implications. Such government institutions such as the Malawi Police Service, The Malawi Defense Force, Government Hospitals and others owe various water boards millions of Malawi Kwachas (BWB [14], LWB [15] and NRWB [16]).

All political parties in Malawi are fairly non-programmatic. This is evidenced by non-adherence of the parties to the parties' constitutions, and at times to some aspects of the constitution of the land. Since the advent of political pluralism in Malawi no single party has had a normal national convention as stipulated in each party' constitution illustrating non-adherence to party constitutions. Use of public funds for party functions has also been observable with the ruling parties using water boards' vehicles, and at times fuel, for ferrying supporters to mass rallies. This has impacted negatively on the operations of the water boards as the limited resources available are stretched to non-water services related functions.

Unlike water supply, sanitation is not yet properly legislated in a harmonized manner. The national sanitation policy of 2008 is an attempt towards legislating sanitation. Currently however, issues of sanitation are only sited by inference in various pieces of legislation such as city bye-laws, Environmental Management Act, Water Resources Act and draft Water and Sanitation Services Act (GoM [17]). Although there is a Directorate of Water Supply and Sanitation, only water supply is clearly legislated in a harmonized manner. This deters developments in sanitation services.

\subsection{The role of civil societies, NGOs, CBO in water and sanitation}

The participation of Civil Societies, Non-Governmental Organisations, and Community Based Organisations in water and sanitation services may be grouped into three different categories. These are policy, structure and management respectively. Most actions of civil societies target policy formulations and policy change. A typical example is the efforts of WaterAid that funded a recent national survey on water and sanitation carried out by MEJN in 2006 [18]. NGOs are often involved in rural water supply through drilling of 
water-bore holes whereas CBOs train local communities in water supply management systems. While NGOs have previously concentrated on service delivery many more are now engaging in social mobilisation and advocacy. Many have been serving as a bridge between local communities and government. Most donors are beginning to regard NGOs as an alternative and effective way of reaching the poor and a mechanism of channelling sizeable percentage of donor funds.

Water Supply Services in Malawi are funded mostly through soft loans and sometimes through grants from the donor community. The sustainability of such funding is very debatable as the political atmosphere is prone to change with changes in ruling parties with time. Cost recovery measures would have been better mechanisms for financing water supply unfortunately this is not the case at the moment.

\subsection{Impact}

In Malawi, poor hygiene, lack of sanitation and low quantity and quality of drinking water contribute to poor health indicators for mothers and children, and impact negatively on the livelihood of women and children as they take on added responsibility for caring for the sick. Water and sanitation are key determining factors. The Human Development Index (HDI) estimates that up to twenty-five percent of schools have no protected water supply and on an average 150 pupils use one latrine. Fifty percent of the health facilities in rural areas do not have proper water supply and sanitation facilities.

Women and children, especially girls suffer the most in situations of inadequate access to water and sanitation. Girls will often stay away from school helping their mothers collect the family's daily supply of water. With as many as half of children under five years suffering from diarrhoea, mothers cannot engage in productive activities as they tend to ill children (UNESCO [19]). According to the HDI, achieving the water and sanitation MDG target would save about US\$ 2 per capita-equivalent to about $12 \%$ of public health spending in sub-Saharan Africa.

In other areas, like Machinga in southern Malawi, fetching water from the most convenient source - the Shire River - puts the lives of women and children at risk of crocodile attacks. In one area, locals estimate almost three deaths a month (UNDP [20]).

\section{Conclusion and recommendations}

The national regulatory framework is fragmented and incomplete. This impacts negatively on water supply but more so on sanitation services. Despite a fairly high renewable water resources per capita of $1374 \mathrm{~m}^{3}$ Malawi has started experiencing a certain degree of water stress due to absence of comprehensive management programme. The country needs to seriously indulge into integrated water resources management that encompasses sanitation. The performance of the country in water supply and sanitation at $66.4 \%$ and $61.9 \%$ respectively is 
good when compared to the regional average of 58\% for water and $36 \%$ for sanitation. However for Malawi to attain the $75 \%$ access national target by 2015 coordinated efforts are required in the water and sanitation sector.

Constraints in the sector include the fragmented regulatory framework, separation of sanitation from water supply, low public expenditure on water supply and sanitation and unwillingness to pay for water supply by the general public. The water and sanitation sector in Malawi requires reorganisation to link sanitation to water supply. Resource allocation to the sector calls for review with respect to national strategies. Water tariff management also calls for review.

Urban areas of the country are better provided for compared to the rural areas at $85.1 \%$ urban and $63.9 \%$ rural, $73.8 \%$ urban and $59.7 \%$ rural, in water supply and sanitation respectively. While efforts must continue in both rural and urban areas enhanced initiatives are required in the rural sector.

The National policy recognises water supply as priority however public expenditure does not reflect this priority. The sector thrives on the participation of civil societies, Community Based Organisations and Non Governmental Organisations.

\section{References}

[1] AfDB/OECD, African Economic Outlook, 2007.

[2] NSO, National Statistics Office of Malawi, Integrated Household Survey, 2005.

[3] UN, United Nations Millennium Development Goals, 2005.

[4] GoM, Government of Malawi, Malawi Poverty Reduction Strategy paper, 2005.

[5] GoM, Government of Malawi, Water and Sanitation Review, 2005.

[6] ADB, African Development Bank: Assessment of Rural and Urban water supply and sanitation sector in Malawi, 2007.

[7] GoM, Government of Malawi, Malawi Millennium Development Goals progress report, 2007.

[8] MoIWD, Ministry of Irrigation and Water Development, Malawi Water Resources Supply and Sanitation Achievements, Annual Report, 2007.

[9] GoM, Government of Malawi, Water Works Act, 1969.

[10] AFRODAD, The Politics of the MDGs and Malawi: A critical Appraisal of the Global Partnership for Development (Goal 8), 2005.

[11] DFID, DFID Malawi - Country Assistance Plan, 2007 - 2011, 2007.

[12] GoM, Government of Malawi, Water Resources Act, 1969.

[13] GoM, Government of Malawi, Water and Sanitation Services Act, 2008.

[14] BWB, Blantyre Water Board Annual Reports, 2005, 2006, 2007.

[15] LWB, Lilongwe Water Board Annual Reports, 2005, 2006, 2007.

[16] NRWB, Northern Region Water Board Annual Reports, 2005, 2006, 2007.

[17] GoM, Government of Malawi, Water and Sanitation Sector Review, 2007.

[18] MEJN, Malawi Economic Justice Network, Report on Water and Sanitation Survey in Malawi, 2006. 
22 Water Resources Management V

[19] UNESCO, The Development of Education in Malawi. Malawi, National Report to $45^{\text {th }}$ Session of the International Conference on Education, Geneva 30 September - 5 October, 1996.

[20] UNDP, Access to Clean Water and Sanitation, Press release of 19th December. 2006. 